\title{
SUBCUTANEOUS STONE FOREST (TREBNJE, CENTRAL SLOVENIA)
}

\author{
PODTALNI KAMNITI GOZD \\ (TREBNJE, OSREDNJA SLOVENIJA)
}

MARTIN KNEZ $^{1} \&$ BOJAN OTONIČAR ${ }^{1} \&$ TADEJ SLABE $^{1}$

${ }^{1}$ Karst Research Institute, ZRC SAZU, Titov trg 2, SI-6230 POSTOJNA, SLOVENIA e-mail: izrk@zrc-sazu.si 


\section{Abstract}

UDC: $551.435 .8(497.4)$

\section{Martin Knez \& Bojan Otoničar \& Tadej Slabe: Subcutaneous stone forest (Trebnje, central Slovenia)}

The stone forest is generally being formed on the dolomitised limestone and dolomite breccia under a thick layer of soil. The stone columns are of regular shape, they attenuate towards their tops and display the typical subcutaneous rock relief.

Key words: stone forest, subcutaneous karst forms, Slovenia.

Izvleček

UDK: 551.435.8(497.4)

Martin Knez \& Bojan Otoničar \& Tadej Slabe: Podtalni kamniti gozd (Trebnje, osrednja Slovenija)

Na brečasti dolomitni kamnini se pod debelimi tlemi oblikuje podtalni kamniti gozd. Kamniti stebri so pravilnih oblik, navzgor se ožijo in imajo značilni podtalni skalni relief.

Ključne besede: kamniti gozd, podtalno oblikovanje krasa, Slovenija. 


\section{INTRODUCTION}

The subcutaneous stone forest has been discovered during the construction of the industrial facilities at the NE border of Trebnje town (Fig. 1,2,3) and represents the first phenomenon of this type in Slovenia. Individual columns attain the height of up to $8 \mathrm{~m}$ and they display typical subcutaneous karst. Prior to the building interventions this stone forest has not been revealed on the surface, since there were only peaks of columns that were protruding for several decimetres out of the thick soil, which could at first sight be considered and classified as smaller karren. Regarding its shapes, size and manner of its formation we may compare it to the renowned Chinese, or more precisely said, the Lunan stone forests. (Knez \& Slabe 2001a; 2001b; 2002).

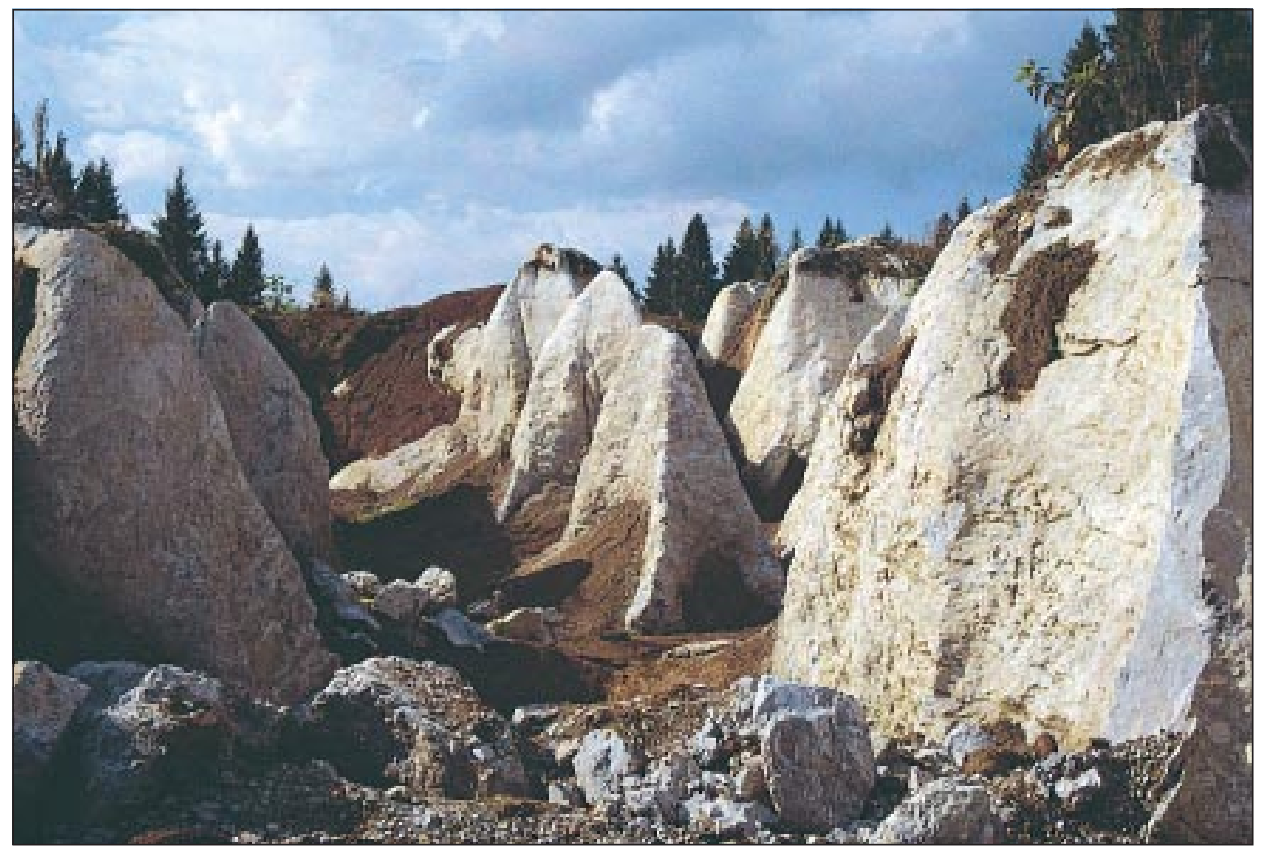

Fig. 1: Subcutaneous stone forest.

\section{GENERAL REGIONAL AND MORPHOLOGICAL OVERVIEW}

The territory between Ljubljana moor, Krško depression, Dobrepolje, Želimlje depression and Gorjanci Mt. is considered as so-called low-land covered karst of Dolenjska (Gams 1974; Kranjc 1990).

On the Triassic dolomites of Dolenjsko Podolje (Dolenjska lowland) the surface drainage prevails, although the significant part of precipitation is also drained vertically into the fissured and porous rock (Habič 1982). The infiltrated water is supplying some smaller yet permanent springs. Although the surface as well as subsurface karst phenomena are generally rare, they are 


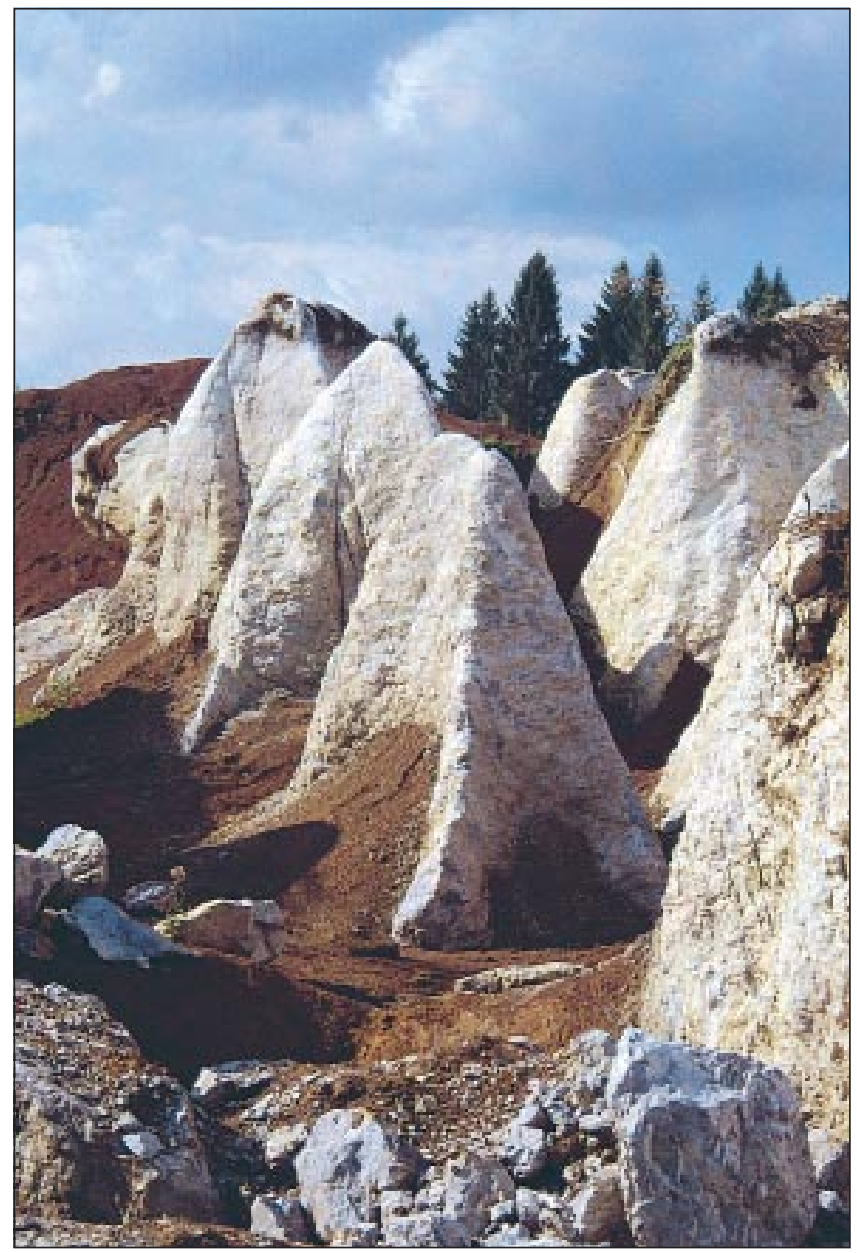

Fig. 2: Stone columns with large runnels. still typical and for that reason we may classified the dolomite karst as a special type of fluvio-karst.

On the predominant dolomite substratum the relief with valleys and at some places with the surface hydrographic network has been developed. The prevailing torrential drainage within the area of the upland Notranjska and Dolenjska affects the formation of steep and deep gorges, which are for the most part incised into broken and crushed fault zones. On the dolomite of the northern Dolenjska, however, considerably lower and more moderate relief has been formed. The karst characteristics of the dolomite are reflected in slight hummocky surface, in typical dry valleys and rare dolines and shallow uvalas. The subsurface drainage is also pointed out by relatively smooth unfurrowed slopes of ridge-like elevations. The evident sign of

karstification are sinkholes, which are opening into the thicker layers of the weathered dolomite material at the bottom of the depressions. Horizontal caves are practically absent in this area.

Relatively large part of the rocky basement of Dolenjsko Podolje is covered by PlioceneQuarterly fluvial sediments. During the time of deposition and afterwards, the fluvial sediments were, especially in the area of the Sava's compressive wedge, at some places raised even up to $450 \mathrm{~m}$ above the present river-bed of the Sava river, whereas the area outside the wedge was elevated to a relatively modest extent (Placer 1999).

Owing to the fact that the soil above the Triassic dolomites is thicker and more cohesive than that lying on limestones and was in the colder Pleistocene climate, due to the seasonal freezing partly impermeable, we may find more signs of former inflows of waters on the boundary limestone (Gams \& Vrišer 1998). 


\section{GEOLOGY OF THE SITE}

The Trebnje area is composed of Triassic and Jurassic shallow marine carbonate rocks (Fig. 3), in places overlain by up to few metres thick Pliocene-Quaternary deposits and soil (Pleničar \& Premru 1977). Scattered erosional patches of the Late Cretaceous deeper marine marl and sandy deposits disconformably overlay Triassic and Jurassic carbonate successions.

Tectonically the area corresponds to the easternmost part of the Hrušica nappe of the Dinaric fold and thrust belt which comprises a part of NE External Dinarides. The area is also a part of post-Miocene Sava compressive wedge, which was subjected to general uplift during Pliocene and Quaternary (Placer 1999).

In the outcrop at Trebnje, a host rock is composed of two lithologies, light grey massive internally stratified dolomitised limestone and grey coarse grained dolomitic breccia which occupies a major part of the outcrop. Locally, the upper part of the pinnacles beneath the soil is slightly silicified.

According to regional geological data (Pleničar \& Premru 1977) and our own investigation the dolomitised limestone corresponds to the Late Triassic dolomite, which mainly consists of inner-platform shallowing-upward peritidal cycles characterised by subtidal light grey to dark grey dolotimised mudstone and intratidal light grey, locally reddish stained laminated dolomitised mudstone.

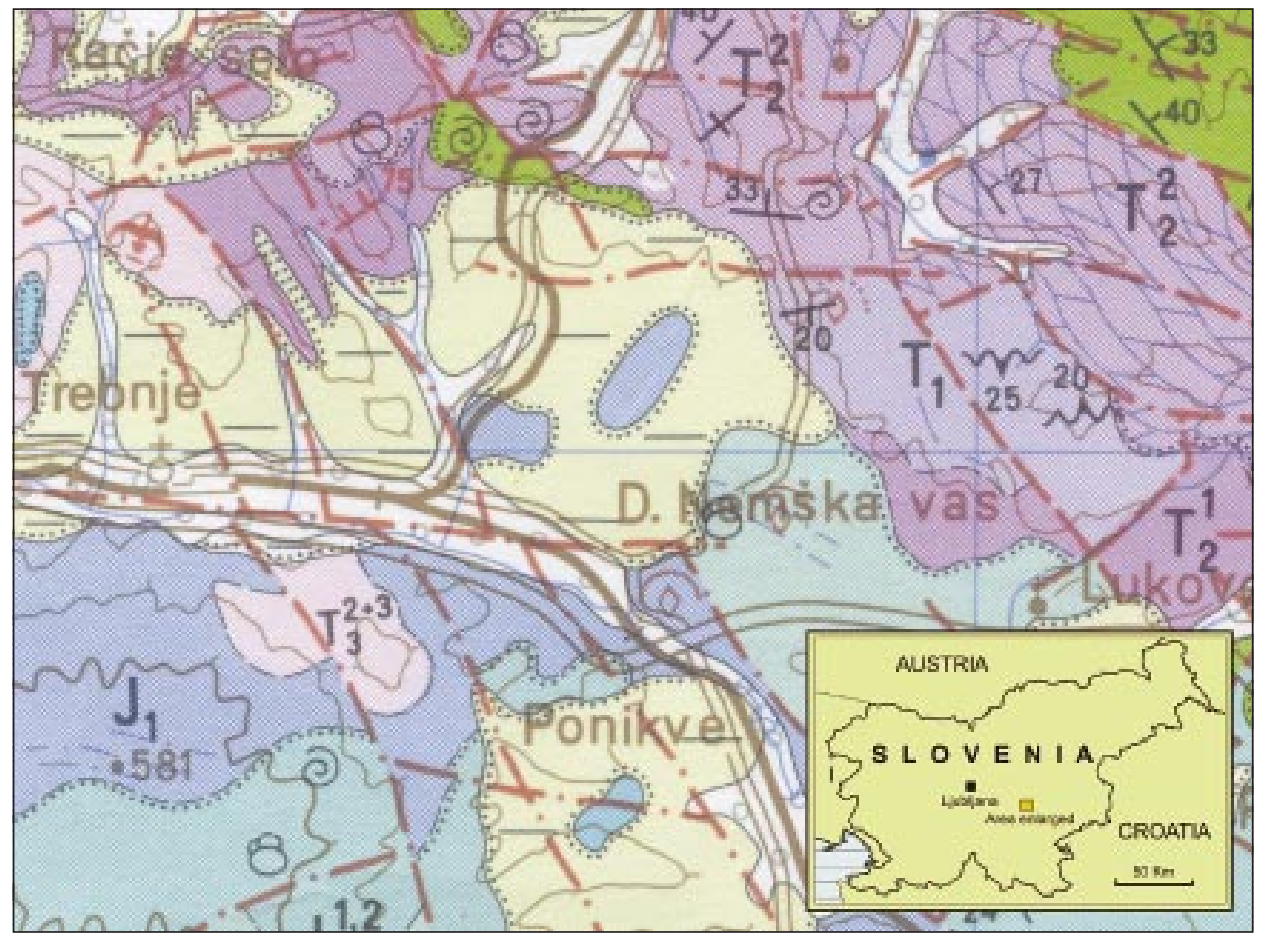

Fig. 3: Geological situation of the Trebnje area (Pleničar et al., 1969) and location of the site (red dot). 


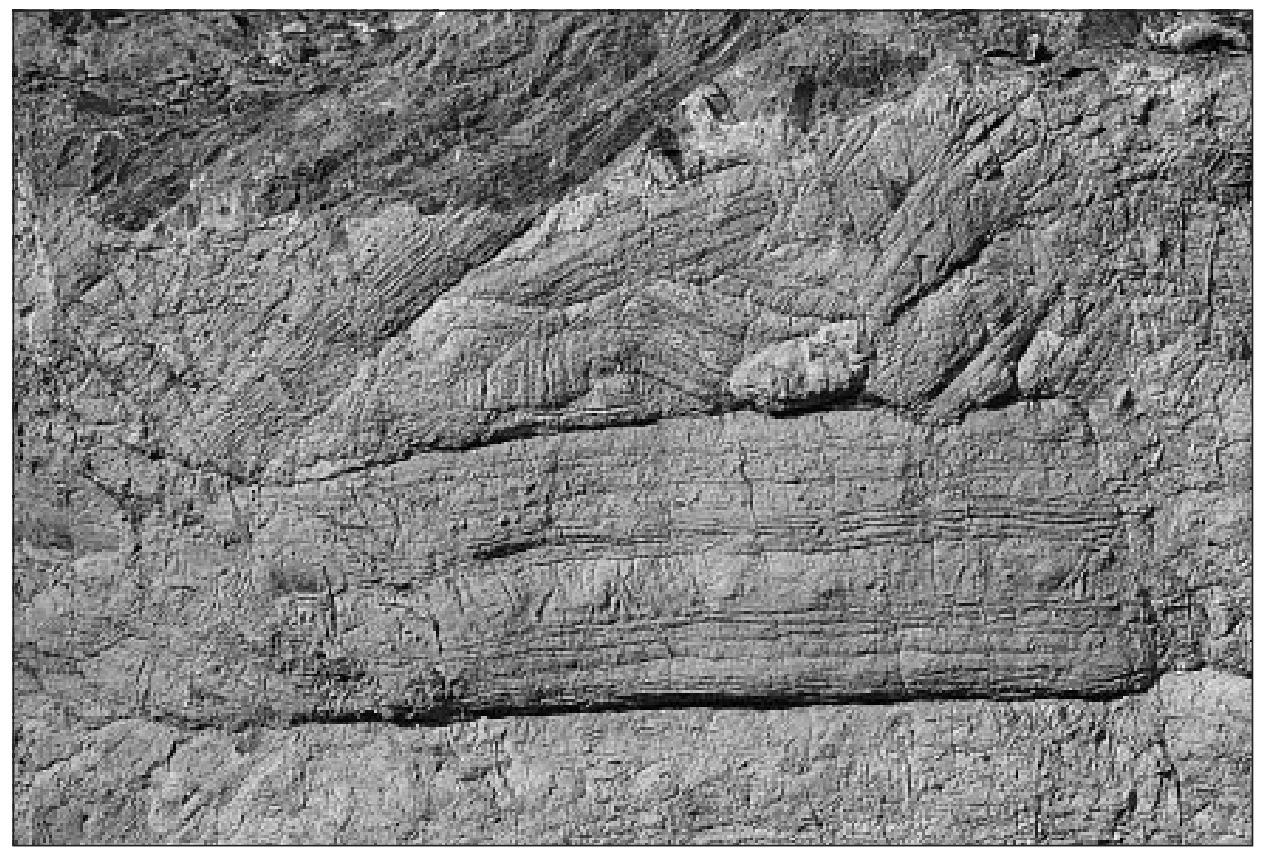

Fig. 4: Rock surface on the dolomite breccia.

The breccia (Fig. 4), which is laterally discordant to approximately $30^{\circ}$ south-westward declining stratified dolomitised limestone, is internally disorganised, with chaotic clast orientation and no apparent internal stratification. Fabrics include both matrix- and clast-supported styles, commonly in close proximity. Breccia clast size is variable, yet it typically ranges from very fine pebble to boulder; coarse pebble to cobble size seems to be the most common. Gravel sorting is poor. Clast shape is variable but slightly elongated forms prevail. Roundness is very low, with most clasts being angular, however, especially smaller ones could be also sub-angular. The clasts reflect lithologies of the enclosing dolomitised limestone exclusively of inner shelf sedimentary facies.

The clasts are immersed in a middle to dark grey, locally reddish and greenish stained dolomitic matrix with no internal structures. The matrix probably resembles the dolomitised mudstones making up the subtidal sediments of the inner platform facies.

The clasts frequently reveal multi-phase locally solutionally widened joints infilled with matrix and/or calcite spar. Some calcite veins cross-cut both the clasts and the matrix. Stiloliths postdate calcite joints.

No index fossils have been discovered in fragments or matrix of the breccia, therefore, the stratigraphic position can only be established on the basis of the superpositional relationships and lithological appearance of the clasts. The time of the breccia formation should be therefore positioned close to the boundary between Triassic and Jurassic.

Despite spatially limited outcrop and the lack of information from the adjacent areas, described features yield enough information to interpret the chaotic breccia as synsedimentary, fault, fissure 
or small graben related, tectonically influenced phenomenon, deposited as gravitational rock fall and/or mass flow deposit which was formed during changing conditions in the formerly relatively monotonous part of the Late Triassic (Early Jurassic?) shallow marine carbonate platform.

Both, breccia and stratified dolomitised limestone are overlain by up to few metres thick soil cover, which displays characteristics of cambisols. No pedogenically unmodified clastic deposits, which presumably overlie carbonate host rock in the adjacent areas, have been found in the study area.

\section{SHAPES OF THE STONE FOREST AND ITS COLUMNS AND THEIR ROCKY RELIEF}

Only $1000 \mathrm{~m}^{2}$ of the above-mentioned stone forest has been uncovered, however its principal formal characteristics could be determined. Subcutaneous columns, regardless whether they are smaller or larger, are both comparatively close to one another, they are ranged into belts, in between of which there are elongated N-S orientated depressions. The columns' peaks are mostly positioned at the same level.

Regarding their shape the columns may be divided into two types. The predominant are those largesized. In their lower part, they occupy up to several square metres large area. They are further carved out in the forms of subterraneous rocky features (Slabe 1998). They were formed out of larger massive bulks of rock, which were not markedly or thickly fissured. Pinnacles of such pillars are bladelike and have

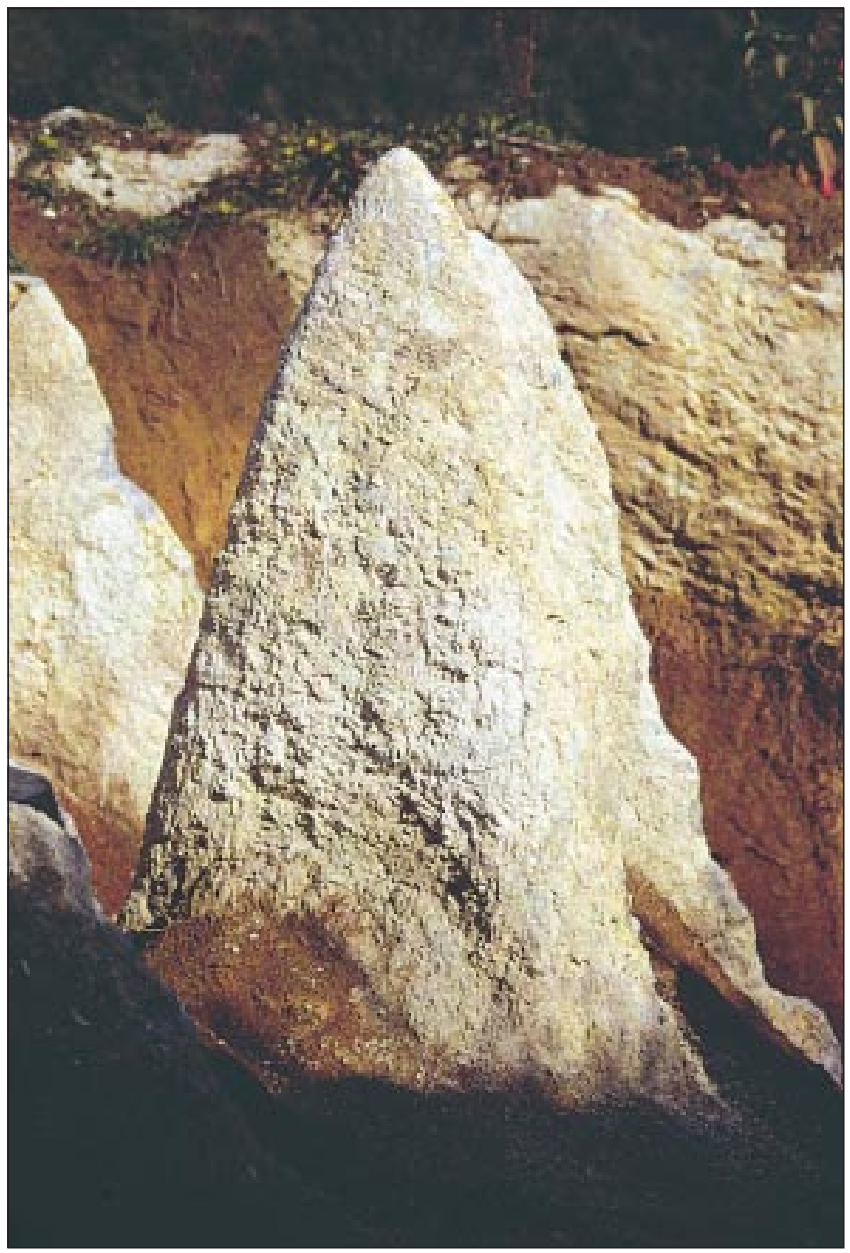

Fig. 5: Rock tooth. 
several sides and they are further carved in the form of the funnel-like channels, beneath which there are large subcutaneous notches.

The second type of the columns is represented by individual (Fig. 5), pointed and less massive structures.

Both markedly taper off towards their apex, which is a characteristics of the subcutaneous shaping of the rock by means of water, which in a dispersed manner percolates from the surface. This assumption was also corroborated by the plaster models of these columns (Slabe 2003).

The most pronounced rocky features, which are carved into the columns are the funnel-like incisions (karren) (Fig. 6) and subcutaneous channels. The diameter of funnel-like incisions at the top of larger columns extends from $10 \mathrm{~cm}$ up to 2 metres, they are of semi-spherical shapes and for the most part represent the orifices (inlets) to the subsoil channels.

Smaller subcutaneous channels (Slabe 1999) measure up to $10 \mathrm{~cm}$ in diameter, whereas larger channels also up to one meter ore more. On the vertical surfaces they are relatively shallow and prove to be deeper only beneath the funnel-like notches. In between their vertical parts one finds also less steep sections, which may broaden into the subcutaneous cups.

In the lower part of columns there are larger pan-like notches, which came into being due to the weathering of the rock. As it seems, at same places, predominantly already few metres under the surface, larger quantity of moisture is being accumulated, which remains preserved for the longer period of time and the corrosion is for that reason even more pronounced.

Prior to this recent "non-natural" unveiling of the columns, it was only their pinnacles that were protruding by $50 \mathrm{~cm}$ to one meter out of the ground, which covered the rock. On the most

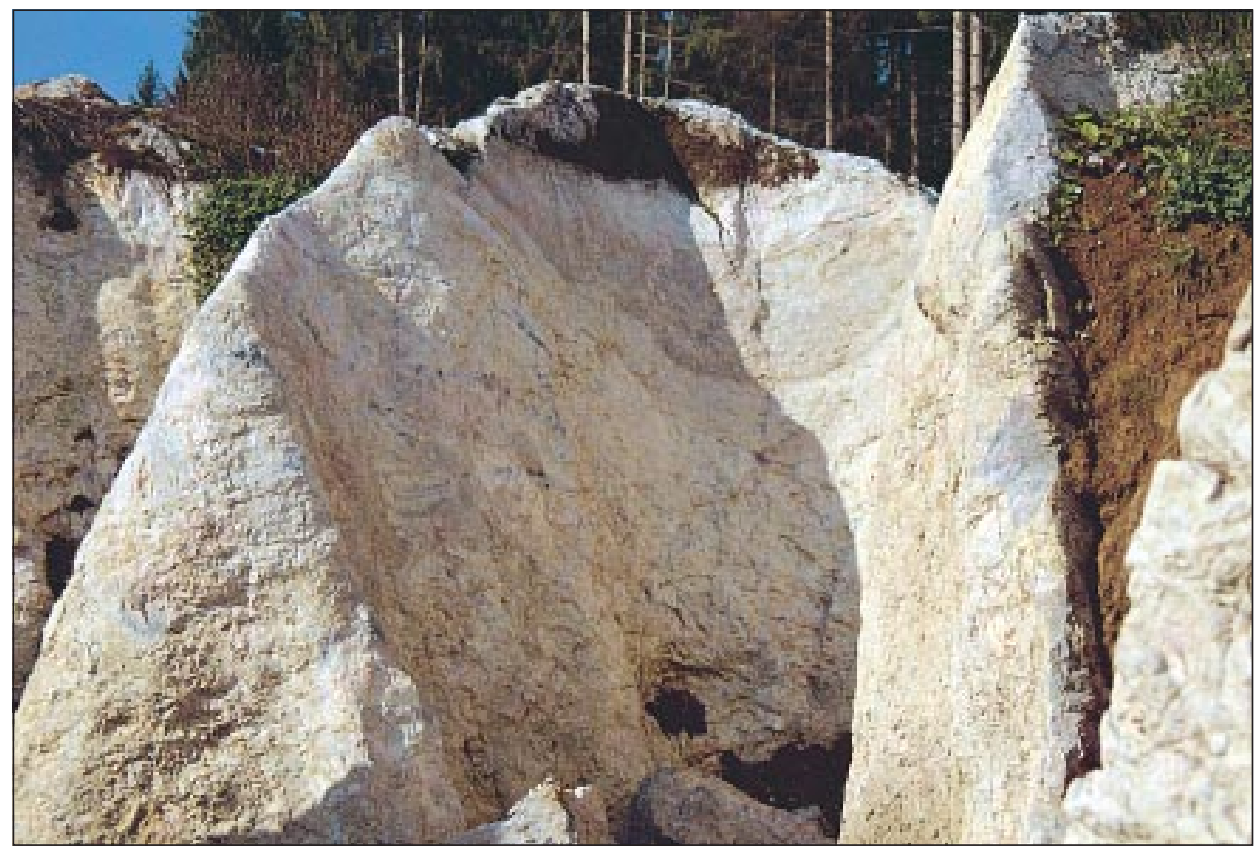

Fig. 6: Funnel-like orifice of the subcutaneous runnel. 


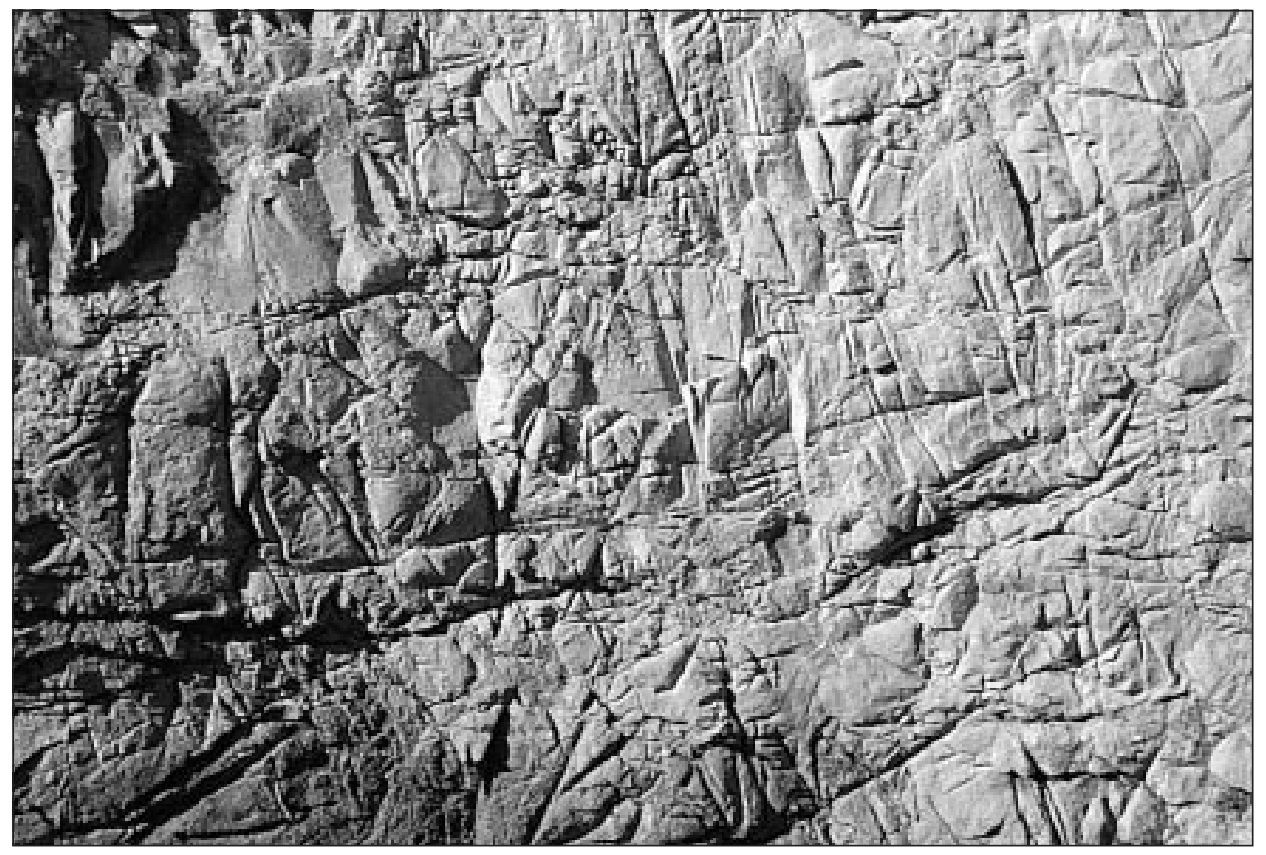

Fig. 7: Boxwork.

massive columns kamenitzas occur. As a rule, flutes, i.e. smaller rocky features, do not develop on this type of rock.

The rock surface may be distinguished between the surface that was positioned below the soil and the other one, which was formed above the soil. The upper part of the former is a carved boxwork (Fig. 7), which, as it seems, occurs due to the faster washing away of the solution, whereas the latter, the lower part, is weathered up to several centimetres deep, it is soft and is rapidly disintegrating. The most markedly weathered is the surface of the subcutaneous notches. The surface of the rock, which was located above the ground, is well washed away, yet, as it is also typical of this type of rock, it is also characteristically "dolomitically" carved. It is interlaced with a mesh of slits, which extend along the calcite veins. Of this type are also the perimeters of kamenitzas. Smoother surface was formed only beneath the moths.

\section{CONCLUSION}

Although the rock is heterogeneous, this fact is not reflected in the shape of the columns. They are of regular forms and are attenuating towards their tops. The rock itself, however, affects the rocky relief of these stone columns. On their surface thus occur only larger rocky features, funnel-like notches, subcutaneous channels and on the surface also the kamenitzas. The flutes on such type of rock are not likely to be found. 
The determination or the assessment of the beginnings of the formation of the stone forest would demand more detailed pedological examination of the soil.

The subcutaneous stone forest represents a significant karst feature, which reveals us the subsoil processes on carbonate rocks as well as the development of the covered karst areas.

In addition to this it is also a very appealing natural sight for the visitors and others interested in karst phenomena.

For that reason it is mandatory to take into consideration this finding also in the further planning of constructions and similar interventions on the karst surface and consequently adopt the appropriate protection measures. These features may, namely, occur also elsewhere, that is, where the described conditions are fulfilled - i.e. the compact rock, interlaced with a network of vertical fissures and a thick cover of fluvial sediments or the soil above them. Furthermore, we may point out that a large part of the karst in the south-eastern Slovenia belongs exactly to such type.

\section{REFERENCES}

Gams, I., 1974: Kras (Karst).- Slovenska matica, 358 str., Ljubljana.

Gams, I. \& Vrišer I. (ur.), 1998: Geografija Slovenije (Geography of Slovenia).- Slovenska matica, 501 pp., Ljubljana.

Habič, P., 1982: Pregledna speleološka karta Slovenije (Speleological map of Slovenia).- Acta carsologica 10, 5-22, Ljubljana.

Knez, M. \& Slabe, T., 2001a: Oblika in skalni relief stebrov v Naigu kamnitem gozdu (JZ Kitajska) (The Shape and the Rocky Relief of Columns in Naigu's Stone Forest (SW China)).- Acta carsologica 30/1, 13-24, Ljubljana.

Knez, M. \& Slabe, T., 2001b: The lithology, shape and rock relief of the pillars in the Pu Chao Chun stone forest (Lunan stone forests, SW China).- Acta carsologica 30/2, 129-139, Ljubljana

Knez, M. \& Slabe, T., 2002: Lithological and morphological properties and rock relief of the Lunan stone forests.- In: Evolution of karst: from prekarst to cessation, edited by F. Gabrovšek, 259-266, Postojna-Ljubljana.

Kranjc, A., 1990: Dolenjski kraški svet (The Karst World of Dolenjska).- Dolenjska založba, 240 pp., Novo mesto.

Placer, L., 1999: Structural meaning of the Sava folds.- Geologija 41, 1991-221, Ljubljana.

Pleničar, M. \& Premru, U., 1969: Tolmač za list Novo Mesto. Osnovna geološka karta SFRJ (Explanations to the map of Novo Mesto. Basic Geological Map of SFRJ) $1: 100000$, Beograd, 61 pages.

Pleničar, M., Premru, U. \& Herak, M., 1977: Osnovna geološka karta SFRJ (Basic Geological Map of SFRJ) $1: 100$ 000, Beograd.

Slabe, T., 1998: Rock relief of pillars in the Lunan stone forests.- In South China Karst, Chen Xiaoping et al., Založba ZRC, 51-67, Ljubljana.

Slabe, T., 1999: Subcutaneous rock forms.- Acta carsologica 28/2, 255-271, Ljubljana.

Slabe, T., 2003: Two experimental modelings of karst rock relief in plaster: subcutaneous "rock teeth" and "rock peaks" exposed to rain, Z. Geomorph. N. F., Berlin - Stuttgart. 